Journal of Indonesian Applied Economics, Vol.6 No.2, 2016: 155-175

\title{
THE EFFECT OF MACROECONOMIC VARIABLES ON THE YIELD SPREAD OF INDONESIAN GOVERNMENT'S BOND ${ }^{1}$
}

\author{
Chandra Utama \\ Faculty of Economics, Catholic University of Parahyangan \\ Shela Selviana Agesy \\ Alumni of Faculty of Economics, Catholic University of Parahyangan
}

\begin{abstract}
This study analyzes the roles of macroeconomic variables, which include interest rate (SBI), Consumer Price Index (IHK), Jakarta Composite Index (IHSG), money supply (JUB) and exchange rate (KURS) on yield spread of government bonds (YSI) in Indonesia. The study employs Error Correction Model (ECM) on Indonesian monthly data from January 2008 to December 2013. The study confirms that SBI and KURS significantly determine the YSI in the short run and the long run but money supply is significant only in the long run. However, YSI is not influenced by IHK and IHSG. Based on term structure of interest rate theory, the study finds that the expected future interest rate is determined by SBI, KURS, and JUB.
\end{abstract}

Keywords: Government bond, Yield spread, Macroeconomic variable

JEL Classifications: G100, E00

\section{INTRODUCTION}

Initially, the issue of government bond is used to meet the need of banking recapitulation as a consequence of the 1997 economic crisis. Besides, it is also used to cover the deficit of Government budget. If in 2000 the government debt was dominated by loans from other countries in the form of bonds, in 2008, the proportion of government's debts was 55\% from the domestic sources (in the form of bonds) and the remaining 45\% from overseas. Meanwhile, in 2013, the proportion of the government's domestic debt was $69 \%$ and $31 \%$ was from other countries (General Directorate of

\footnotetext{
${ }^{1}$ The author expresses his/her gratitude to Dr. Miryam B. Lilian Wijaya for the comment and input which is very helpful for this research.
} 
Debt Management (DJPU) 2013). This development shows that there is a restructrization of the government's debt from a loan into a better security since the interest rate requirement, term of maturity, and date of interest payable are decided by Indonesian Government.

Simultaneous bond issued by the government increases the outstanding (amount) of the government bond in the domestic bond market. If in 2000 the total outstanding of the government bond was Rp. 31.63 trillions, in 2008 it increased to Rp. 525.69 trillions. In fact, in 2013, the total outstanding of the government bond reached Rp. 995.25 trillions (Financial Service Authority (OJK) 2014). Henceforth, the development of the government bond triggers the increase of outstanding of company bond, which in 2000, 2008, and 2013 was as much as Rp.19.89 trillions, Rp.72.98 trillions, and Rp.316.74 trillions respectively.

As mentioned by Blanchard (2011), between one bond and another will be different in two dimensions, i.e. default risk and maturity. The former risk obviously appears only in company bonds whereas the latter also exists in the government bond. Next, Blanchard (2011), FRBSF (2003), Wu (2001), Ang and Piazzesi (2001), and Evans and Marshall (2001) mentioned that the second risk occurs due to the change of macroeconomic variables which transform market expectations to the economy which influences the investment output in the future. This market estimation in the future is illustrated by yield curve or known as term structure of interest rate. Yield curve with positive inclination demonstrates the estimated yield in the future and it will increase and expand the economy. Meanwhile, if the opposite applies, the market foresees economic deceleration.

Several studies have been conducted to find out the effect of macroeconomic variables on the estimated yield in the future. To measure the estimation, yield spread (the difference between bond yield and long and short maturity) is used. A study by Fah (2011) in Malaysia using growth variable of PDB, inflation, interest rate, money supply, production index, trade balance, exchange rate, and Malaysian government yield spread with a maturity of 10 years and 1 year, found that macroeconomic 
The Effect of Macroeconomic Variables On The Yield Spread on Indonesian Government's Bond

variables affecting yield spread include GDP growth, money supply, industrial production, and trade balance. In the meantime, a study conducted by Ahmad et al (2009) found that consumer price index and interest rate have the most significant impact on the yield spread movement change. Also, Min (1998) who analysed the determinants of bond's yield spread in 11 developing countries from 1991 to 1995, found that debt to GDP ratio, debt service ratio, net foreign assset, international reserves to GDP ratio, inflation rate, oil price, and exchange rate significantly affect yield spread in terms of liquidity, solvability, and macroeconomic variables.

Batten et al (2006) studied government bond in Pacific Asia International Market, i.e. China, Korea, Malaysia, Thailand and Phillipines with benchmark of US Treasury. They found that bond yield spread in Asian countries has a negative correlation with an interest rate change. In addition, exchange rate and stock market variables have a significant influence on the change in yield spread, of which Philippines is the only country where the stock market is negatively correlated with yield spread, while exchange rate is positively correlated with the yield spread. Finally, the study held by Sihombing et al (2012) found that macroeconomic variables affecting yield spread in Indonesia include consumer price index (IHK) and BI rate.

Based on the previous studies, this study aims to examine the effect of macroeconomic variables (BI rate, IHK, IHSG, money supply, and exchange rate) on yield spread. Yield spread is calculated using the difference of government bond yield in 3 year maturity (short term) and 10 year maturity (long term). The selection of the government bond is conducted because the government bond is a benchmark for company bonds (Bank of Indonesia 2006). In fact, the proportion of government bond in 2013 in the Indonesian bond market was 75,9\% (OJK, 2013). Next, the government bond has a default risk close to zero and homogenous; thus, the remaining risk is the maturity.

In the second part of the paper, it will discuss theoretical review used in this study. Research methodology and model specification is discussed in the third part. In the fourth part, it discussess the estimation results. Finally, in the last part, it concludes. 


\section{THEORETICAL REVIEW}

Yield Spread is the difference between bond and different maturities. Yield spread can be influenced by the bond's characteristics (Fabozzi et al, 2010). Besides, the movement of yield spread can also be affected by the shock that exists in the macroeconomy (Fah, 2011). The shock in macroeconomy can make the yield spread getting wider or smaller. In general, this yield spread is used by investors to determine the expected interest rates as well as the economy in the future. The following are several basic concepts which explain the relationship between macroeconomic variables and yield spread.

\section{The Interest Rate of the Central Bank}

According to Blanchard (2011), bond price $\left(P_{t}\right)$ is determined based on the cash flow value that can be obtained from bond $\left(D_{t}\right)$ and interest rate $\left(i_{t}\right)$. The price of bond can be explained below:

$$
P_{t}=\sum_{t=0}^{n} \frac{D_{t}}{\left(1+i_{t}\right)}
$$

In equation (1), if the interest rate increases, the bond price will decrease, while if the interest rate decreases, the bond price will increase. The longer the maturity, the higher percentage of bond price change will be, provided the interest changes. However, the current interest change and the expected interest rate in the future determine how significant the bond price will change. Bond price is directly related to yield of bond. Consequently, the short term interest rate and the estimated short term interest rate in the future determine the amount of bond yield in different tenors.

According to Blanchard (2011), the decrease of interest rate results in the decrease of short term bond yield. Market actors estimate that in the long run, the short term interest will return to the initial point, so the long term bond yield will be higher than the short term more than the usual condition. The decrease of interest causes positive yield spread become bigger. On the other hand, if the market players 
predict that long term interest will go down proportionally as the decrease of the short term, yield spread will not change.

\section{Consumer Price Index}

Consumer price index (IHK) is an index which measures the average price of goods and services, whereas the percentage of its change is called inflation. Investors who invest with certain risks will set a target on the real yield $\left(Y_{r, t}\right)$ from their investment. The real yield value is determined by the amount of its yield's nominal $\left(Y_{n, t}\right)$, inflation expectation, $\left(\pi_{t}^{e}\right)$, and other factors $\left(x_{t}\right)$; thus, it can be written as:

$$
Y_{r_{0}, t}=Y_{n_{2}, t}-\pi_{t}^{B}-x_{t}
$$

To simplify it, it is assumed that $x_{t}$ is constant, so the equation (2) is rewritten as

$$
\begin{aligned}
& Y_{r, t}=Y_{n_{,} t}-\pi_{t}^{\theta} \\
& Y_{r_{t} t}+\pi_{t}^{e}
\end{aligned}
$$

Equation (4) shows that the bigger the $\pi_{t}^{e}$, the bigger the $Y_{n, t}$ (which is asked by investors). Based on the current inflation rate $\left(\pi_{t}\right)$, investors will the quantity of $\pi_{t}^{e}$ in the future. When there is an increase in the IHK, short term will increase. If investors expect that the common price will return in a long run, the yield spread will decrease. In contrast, if investors estimate that the current price represents the future price, the long term yield will also go up proportionally, so the yield spread will not be affected.

\section{Jakarta Composite Index (IHSG)}

In investing, investors take into account the rate of return and risk and avoid risk (risk averse). Stocks basically have higher risk than bonds, even though they promise a higher return. Investment portfolio made by investors is explained as follows (Handa 2009)

$$
E\left(\mu_{p}\right)=E\left(\mu_{s}\right) x_{S}+E\left(\mu_{b}\right) x_{b}
$$


Where expected result of portfolio, $\mathbb{E}\left(\mu_{p}\right)$, is determined by the average expected result from stock, $E\left(\mu_{s}\right)$, and bond, $E\left(\mu_{b}\right)$ times the proportion of each asset in portfolio, $x_{S}$ and $x_{b}$. Meanwhile, the estimated risk of portfolio which is measured by the root of the varians portfolio $\left(\sigma \quad{ }_{p}^{2}\right)$ can be written as

$$
E\left(\sigma^{2}\right)=E\left(\sigma_{S}^{2}\right) x{ }_{s}^{2}+E\left(\sigma_{b}^{2}\right) x{ }_{b}^{2}+2 \rho_{s, b}^{e} E\left(\sigma_{S}\right) E\left(\sigma_{b}\right) x_{S} x_{b}
$$

Where $\sigma_{s}$ and $\sigma_{b}$ are the standard deviations of stock, and $\rho^{e}{ }_{s, b}$ is the estimated correlation between stock and bond.

If stock return increases due to an increase in price, the maximum portfolio composition for investors alters because investors raise the stock proportion in their portfolio. The increasing stock demand leads to a decline in bond demand and price, so the yield increases. This increasing yield is a short term yield. When in a long run, investors expect that the stock market will be normal, the yield spread will go down on the opposite side. If investors estimate that stock price increase keeps happening proportionally, the yield spread will remain the same. The estimated stock return in a term is usually arranged based on the current change in stock price.

\section{Money Supply}

Money supply determines the amount of saving that can be invested. Economic equilibrium occurs when saving is equal to investment, I=S. In figure 1 , it is shown when there is an increase of money offer, the movement of curve $M_{s 1}$ to $M_{s 2}$, results in overfunding in the society, so saving rises, demonstrated by the shifting curve $S_{1}$ to $S_{2}$. Overfunding owned by the society leads to the increasing demand of securities including bond, shown by the displacement of curve $B_{d 1}$ to $B_{d 2}$. When demand for obligation rises, the price of obligation will also increase, and yield will decrease. If the market players predict that in a long run that money supply will go back to normal, the yield spread goes up. 


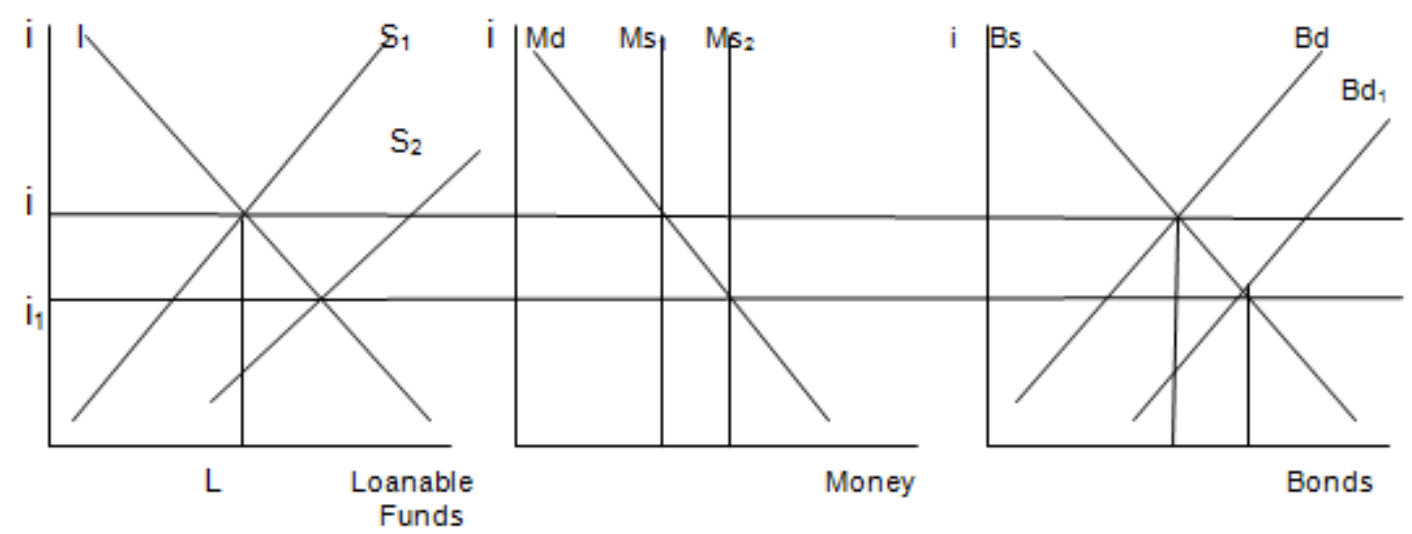

Figure 1. Loanable Funds

Source: Lewis and Mizen (2000)

\section{Holding Obligation}

In holding an asset (i.e. oligation), investors will have to face two choices; they are holding domestic obligation or holding foreign obligation. To determine this investment decision, investors rely on the expected exchange rate. Whether the exchange rate in the future will be depreciated or appreciated will affect return obtained by investors.

Investors have to choose between domestic obligation or foreign obligation. If they buy the domestic obligation, they will get domestic yield as much as $i_{t}$ whereas if they buy foreign obligation, they will receive yield as much as $i_{t}^{*}$ times the current exchange rate, $E_{t}$, divided by the expected exchange rate in the future, $E_{t+1}^{e}$. This condition is called interest rate parity which is written as the following:

$$
\left(1+i_{t}\right)=\left(1+i_{t}\right)\left(\frac{E_{t}}{E_{t+1}^{\theta}}\right)
$$

If the domestic currency suffers from depreciation, the demand for domestic obligation will decline, so the short term yield will increase. If in the long run, the exchange rate is predicted to recover, the yield spread decreases. In contract, if the long term exchange rate will proportionally turn to the current change, the yield spread does not change.

\section{RESEARCH METHODOLOGY AND MODEL SPECIFICATION Research Methodology}


The data used in this study are monthly time series from January to 2008 to January 2013. To obtain the yield spread, this study uses the Indonesian government bond with 10 year and 3 year maturity. Meanwhile, the secondary data include monthly BI rate (SBI), Consumer Price Index (IHK), Jakarta Composite Index (IHSG), money supply (JUB), and exchange rate (KURS). These secondary data are obtained from Bank of Indonesia, PT Dana Reksa, and Central Bureau of Statistics.

Prior estimating the long and short term effect of macroeconomic variables on yield spread, the empirical model test is conducted using the methods of Akaike Information criteria (AIC) and Final Prediction Error (FPE). Meanwhile, the test of stationary level as well data integration of first difference is conducted using the Augmented Dickey-Fuller (ADF) test. The existence of cointegration model, which is the requirement in the ECM model, is estimated by the Johansen Cointegration. To come up with residual value as the Error Correction Term (ECT) in the ECM model, this study uses residual from the long term model by employing Ordinary Least Squares (OLS). To find out the short term influence of macroeconomic variables on yield spread, ECM model is used. Once the long term and ECM model are estimated, a classical assumption test of multicolinearity and heteroscedasticity are conducted using the test of White-heteroscedastcity, while the autocorrelation is tested using the Durbin-Watson. Meanwhile, to test the heteroscedasticity in the ECM model, the Whiteheteroscedasticity and autocorrelation tests are conducted using Breusch-Godfrey Serial Correlation LM test.

\section{Model Specification}

To find the ECT value in the ECM, the following regression model in equation (8) is applied

$$
Y S I_{t}=\beta_{0}+\beta_{1} S B I_{t}+\beta_{2} I H K_{t}+\beta_{3} I H S G_{t}+\beta_{4} J U B_{t}+\beta_{5} K U R S_{t}+\varepsilon_{t} .
$$

In equation (8), the spread of the government bond, $Y S I_{t}$, is determined by BI rate, $S B I_{t}$, consumer price index, $I H K_{t}$, Jakarta Composite Index, $I H S G_{t}$, money supply (M2), $I U B_{t}$, and the exchange rate of rupiah to the US dollar, $K U R S_{t}$, whereas $\varepsilon_{t}$ is the error 
The Effect of Macroeconomic Variables On The Yield Spread on Indonesian Government's Bond

term (residual) which, in the ECM model, is used as the ECT. Equation (8) also demonstrates the long term effect of macroeconomic variables on yield spread.

Once the residual value of equation (8) is obtained, the ECM is estimated. ECM used in this study can be arranged as

$$
\begin{aligned}
\text { DYSI }_{t}= & \alpha_{0}+\alpha_{1} D S B I_{t}+\alpha_{2} \text { DIHK }_{t}+\alpha_{3} \text { DIHSG }_{t}+\alpha_{4} \text { DJUB }_{t}+\alpha_{5} \text { DKURS }_{t} \\
& +\alpha_{6} e E C T_{t-1}+\varepsilon_{t}
\end{aligned}
$$

Where $D$ represents the first difference from the variables. In the meantime, the ECT can be defined as

$E C T_{t}=Y S I_{t}-\beta_{0}-\beta_{1} S B I_{t}-\beta_{2} I H K_{t}-\beta_{3} I H S G_{t}-\beta_{4} J U B_{t}-\beta_{5} K U R S_{t}$

Therefore, the ECM can be rewritten into

$$
\begin{aligned}
& \text { DYSI }_{t}=\alpha_{0}+\alpha_{1} D_{S B I_{t}}+\alpha_{2} \text { DIHK }_{t}+\alpha_{3} \text { DIHSG }_{t}+\alpha_{4} \text { DJUB }_{t}+\alpha_{5} \text { DKURS }_{t} \\
& \quad+\alpha_{6}\left(Y I_{t}-\beta_{0}-\beta_{1} S B I_{t}-\beta_{2} I H K_{t}-\beta_{3} I H S G_{t}-\beta_{4} J U B_{t}-\beta_{5} \text { KURS }_{t}\right)_{t-1}+\varepsilon_{t}
\end{aligned}
$$

$\alpha_{i}$ and $\beta_{i}$ represent the short-term and long-term effects of the independent variables on $\mathrm{YSI}_{t}$. A good and valid ECM model is then expected to have a significant ECT (Insukindro, 1991), which can be represented in the statistical test result on ECT coefficient.

\section{DISCUSSION AND ESTIMATION RESULT}

\section{Empirical Model Test}

The selection of model is an important measure in empirical modeling. Faults in determining the correct function form lead to problems in specification and inconsistent estimation parameters. In this case, this study employs the criteria test of Akaike Information criteria (AIC) and Final Prediction Error (FPE) to select variables that will be used in the model.

Table 1. AIC and FPE Calculation Result

\begin{tabular}{|c|c|c|}
\hline Step & AIC $=\left[\frac{R S S}{T}\right] \times e^{(2 k / T)}$ & $F P E=\left[\frac{R S S}{T}\right] \times \frac{T+k}{T-k}$ \\
\hline 1 & 0.154508 & 0.154511 \\
\hline
\end{tabular}




\begin{tabular}{|l|l|l|}
\hline 2 & 0.152949 & 0.152957 \\
\hline 3 & 0.125076 & 0.125090 \\
\hline 4 & 0.118707 & 0.118734 \\
\hline 5 & 0.105126 & 0.105167 \\
\hline 6 & 0.092893 & 0.092950 \\
\hline
\end{tabular}

Source : Authors' Calculations

The result of model test is then compared from every step conducted. If the AIC and FPE values of each step are smaller than the values from the the previous step, the variables then can be used in the model. As presented in table 1, step 2 of the AIC and FIP are smaller than those of step 1, then step 4 is smaller than step 3, while step 6 is smaller than 5 . Therefore, all the variables that will be used are proper in this study.

\section{Unit Root Test}

Unit root test to all variables used is necessary to meet the validity of ECM analysis. The data is called stationary if they can fulfill these three elements, i.e. possessing a constant average, a constant variance, and a constant covariance in every time unit (Thomas, 1997). Table 2 presents the result of the unit root test using the Augmented Dickey Fuller test at level phase. As presented in table 2, there is only one stationary variable at the level phase, i.e. YSI variable (at the significance level of 5\%) while SBI, IHK, IHSG, JUB, and KURS are non stationary.

Table 2. Unit Root Test at the Level Phase

\begin{tabular}{|c|c|c|c|}
\hline Variable & ADF Value & Probability & Description \\
\hline YSI & -3.359419 & 0.0158 & Stationary \\
\hline SBI & -1.745498 & 0.4043 & Non Stationary \\
\hline IHK & -2.823976 & 0.0601 & Non Stationary \\
\hline IHSG & -0.584149 & 0.8668 & Non Stationary \\
\hline JUB & 2.272225 & 0.9999 & Non Stationary \\
\hline KURS & -1.639015 & 0.4574 & Non Stationary \\
\hline
\end{tabular}

Source : Authors' Calculations 
The Effect of Macroeconomic Variables On The Yield Spread on Indonesian Government's Bond

As only one variable that stationary, we need to conduct the Augmented Dickey Fuller phase at first-difference phase. As presented in table 3, at first difference, all the variables used in this study are integrated (stationary) with a probability value of below $5 \%$. The stationary condition at a similar degree is one of the requirements to see the potential relationship and to avoid a spurious regression.

Table 3. Unit Root Test at the First Difference Phase

\begin{tabular}{|c|c|c|c|}
\hline Variable & ADF Value & Probabilitty & Description \\
\hline Yield Spread & -6.933019 & 0.0000 & Stationary \\
\hline Interest Rate & -3.313056 & 0.0180 & Stationary \\
\hline IHK & -6.058594 & 0.0000 & Stationary \\
\hline IHSG & -4.123914 & 0.0017 & Stationary \\
\hline JUB & -10.23920 & 0.0001 & Stationary \\
\hline Exchange Rate & -3.170666 & 0.0261 & Stationary \\
\hline
\end{tabular}

Source : Authors' Calculations

\section{Cointegration Test}

Following the unit root test, the next step is conducting the cointegration test to see the presence of long term relationship amongst variables. Johansen test of cointegration test result is presented in table 4, showing that the Unrestricted Cointegration Rank Test (Trace) at $a=5 \%$ shows at least 4 cointegration equation. As for the test using Unrestricted Cointegration Rank Test (Maximum Eigenvalue), it demonstrates that there are at least 2 cointegration variables.

Table 4. Cointegration Test Using Johansen Contegration Test

\begin{tabular}{|c|c|c|c|c|}
\hline \multicolumn{5}{|c|}{ Unrestricted Cointegration Rank Test (Trace) } \\
\hline $\begin{array}{l}\text { Hypothesized } \\
\text { No. of } \mathrm{CE}(\mathrm{s})\end{array}$ & Eigenvalue & $\begin{array}{c}\text { Trace } \\
\text { Statistic }\end{array}$ & $\begin{array}{c}0.05 \\
\text { Critical Value }\end{array}$ & Prob.** \\
\hline None * & 0.469853 & 136.6852 & 95.75366 & 0.0000 \\
\hline At most $1 *$ & 0.453874 & 92.89766 & 69.81889 & 0.0003 \\
\hline At most $2 *$ & 0.257189 & 51.15920 & 47.85613 & 0.0237 \\
\hline At most $3 *$ & 0.212377 & 30.64454 & 29.79707 & 0.0399 \\
\hline
\end{tabular}




\begin{tabular}{|c|c|c|c|c|}
\hline $\begin{array}{l}\text { At most } 4 \\
\text { At most } 5\end{array}$ & $\begin{array}{l}0.174664 \\
0.013333\end{array}$ & $\begin{array}{l}14.17174 \\
0.926169\end{array}$ & $\begin{array}{l}15.49471 \\
3.841466\end{array}$ & $\begin{array}{l}0.0783 \\
0.3359\end{array}$ \\
\hline \multicolumn{5}{|c|}{$\begin{array}{l}\text { Trace test indicates } 4 \text { cointegrating eqn(s) at the } 0.05 \text { level } \\
* \text { denotes rejection of the hypothesis at the } 0.05 \text { level } \\
* * \text { MacKinnon-Haug-Michelis (1999) p-values } \\
\text { Unrestricted Cointegration Rank Test (Maximum Eigenvalue) }\end{array}$} \\
\hline $\begin{array}{l}\text { Hypothesized } \\
\text { No. of CE(s) }\end{array}$ & Eigenvalue & $\begin{array}{l}\text { Max-Eigen } \\
\text { Statistic }\end{array}$ & $\begin{array}{c}0.05 \\
\text { Critical Value }\end{array}$ & Prob.** \\
\hline None * & 853 & 752 & 40.07757 & 0.0 \\
\hline At most $1^{*}$ & 0.453874 & 41.73846 & 33.87687 & 0.0047 \\
\hline At most 2 & 0.257189 & 20.51466 & 27.58434 & 0.3066 \\
\hline At most 3 & 0.212377 & 16.47280 & 21.13162 & 0.1984 \\
\hline At most 4 & 0.174664 & 13.24557 & 14.26460 & 0.0720 \\
\hline At most 5 & 0.013333 & 0.926169 & 3.841466 & 0.3359 \\
\hline
\end{tabular}

Max-eigenvalue test indicates 2 cointegrating eqn(s) at the 0.05 level

* denotes rejection of the hypothesis at the 0.05 level

**MacKinnon-Haug-Michelis (1999) p-values

Source : Authors' Calculations

\section{Estimation Result of the Long Run Model}

In equation (12) as follows, it can be seen the estimation result of long run model. Then, the residual of this model will be used as ECT variable in ECM model. $Y I_{t}=2,13-0,333 S B I_{t}-0,004 I H K_{t}+0,0004 I H S G_{t}-0,0000012 J U B_{t}+0,0003 K_{U R S}$
t-stat: (2.915)
$(-5.526)$
$(-1.073)$
(2.315)
$(-4.126)$

(3.506)

Prob: (0.0049)

$(0.0000)$

$(0.2873)$

$(0.0237)$

$(0.0001)$

(0.0008)

$\mathrm{R}^{2} \quad: 0.5223$

F-stat: 9.649 Prob(F-stat): 0.000001

White Heteroscedasticity test: Obs*R-squared : 9.320891

Prob. Chi-Square(20):0.9789

DW-Stat: 0.915 
Equation (12) indicates that SBI, IHSG, JUB, and KURS variables significantly affect YSI (prob valua t-stat less than $5 \%$ ), whereas IHK is insignificant. While the influence of SBI and JUB are negative, that of KURS is otherwise. The F-statistic value as much as 9.6487 or probability as much as 0.0001 means that independent variables altogether affect the yield spread. Besides, $\mathrm{R}^{2}$ as much as $52,2 \%$ shows the ability of the model in predicting the movement of YSI.

The first classic assumption test on equation (12) is multicolinearity, i.e. a condition in which one or more independent variables have a liniar relation with each other. One of the ways to analyze the existence of multicolinearity is by using correlation matrix. If the correlation value between independent variables is more than 0,8 , multicoliniarity can be a serious problem (Gujarati 2003, 359). In table 5, it is shown that there is no correlation between independent variables which is bigger than 0.8 ; therefore, it can be concluded that there is no multocoliniarity issue in the model.

Table 5. Correlation between independent variables

\begin{tabular}{|c|c|c|c|c|}
\hline & SBI & IHSG & JUB & KURS \\
\hline SBI & 1 & -0.739427 & -0.624571 & 0.399970 \\
\hline IHSG & -0.739427 & 1 & 0.793656 & -0.254991 \\
\hline JUB & -0.624571 & 0.793656 & 1 & 0.1381621 \\
\hline KURS & 0.399970 & -0.254991 & 0.138162 & 1 \\
\hline
\end{tabular}

Source : Authors' Calculations

The next classical test is the heteroscedasticity test by using White heteroskedastiscity test. This test is conducted by regressing the squared residual with independent variables, squared independent variables, and multiplication between independent variables. After that, the $\mathrm{R}^{2}$ value is used to calculate $\chi^{2}$, where $\chi^{2}=$ 
$\mathrm{n}^{*} \mathrm{R}^{2}$. The criteria used are if $\chi^{2}$ calculation is smaller than table $\chi^{2}$, the zero hypothesis which states that there is no heteroscadiscity in the model is accepted. Otherwise, if the probability value is more than $5 \%$, then there is no heteroscadiscity. The $\chi^{2}$ value calculated as much as 9.320891 is smaller than the critical value $\chi^{2}$ as much as 31.4104 or Prob. Value as much as 0.9789 is bigger than $5 \%$, so it can be concluded that there is no heteroscedasticity.

The third assumption test in the long run model is the Durbin Watson. For regression with 5 independent variables and 72 observations, obtained value of $d_{l}=1.58$ and $d_{u}=1.64$, so the value of $4-d_{u}=2.36$ and $4-d_{1}=2.42$. The value of DW-Stat. as much as 0.915 indicates a positive autocorrelation. To improve the long term equation, the Cochran-Orcutt iterative method is used next.

From equation 13 it can be seen that the DW-Stat. value (1.842) is in the rejection area between $d_{u}=1,64$ a nd $4-d_{u}=2,36$, so it can be concluded that there is no autocorrelation. Similarly, the calculated $\chi^{2}$ value 18.146 is smaller than the $\chi^{2}$ critical value as much as 40.1132 or Prob. Value as much as 0.899 is more than $5 \%$ which means that there is no heteroscedasticity.

\begin{tabular}{|c|c|c|c|c|}
\hline $\begin{array}{l}\text { t-stat: }(2.288) \\
(2.461)\end{array}$ & $(-3.241)$ & $(-0.930)$ & $(1.233)$ & $(-2.489)$ \\
\hline $\begin{array}{l}\text { Prob: }(0.0255) \\
(0.0166)\end{array}$ & $(0.0019)$ & $(0.3561)$ & $(0.2221)$ & $(0.0154)$ \\
\hline \multicolumn{5}{|c|}{$+0.572(A R 1)$} \\
\hline
\end{tabular}

t-stat: (5.349)

Prob.: (0.0000) 
$R^{2} \quad: 0.5979$

F-stat: $15.859 \quad$ Prob(F-stat): 0.000000

White Heteroscedasticity test: Obs*R-squared : $18.146 \quad$ Prob. Chi-

Square(20):0.899

DW-Stat: .842

Based on the same equation, the SBI, JUB, and KUR significantly influence YSI (the prob t-stat value below 5\%), whereas IHK and IHSG are insignificant. The conclusion of equation 13 is different from the long run equation (equation 12) which shows the long term influence of IHSG. The effect of SBI and JUB is negative while KURS is positive. The F-statistic value of 15.859 or probability 0.0000 indicates that all independent variables altogether affect the yield spread. In addition, $\mathrm{R}^{2}$ demonstrates that regression can explain the movement of yield spread as much as $59.79 \%$. In this regression that has been improved, it can be seen that the IHSG which previously influences yield spread, becomes statistically non-influential.

\section{ECM Estimation Result}

After estimating the long run model (equation 13), the residual value from the equation is used as ECT variable in ECM model. The following is the estimation result of ECM. In the above ECM equation (equation 14), ECT coefficient, i.e. -0.367 is significant (prob. value $=0.0077$ ) so the ECM model is considered valid and there is a long term relationship. It can be seen in the equation 14 that DSBI and DKURS significantly affect yield spread (prob t-stat value below 5\%) whereas IHK and IHSG are insignificant. SBI and JUB have a negative impactwhile KURS is the opposite. The F-statistics $(3,0416)$ or probability $(0,01112)$ indicates that independent variables altogether influence the yield spread. Moreover, $\mathrm{R}^{2}$ proves that regression can explain the movement of yield spread as much as $22.19 \%$. 
DYSI $_{t}=-0,037-0,355$ DSBI $_{t}-0,003$ DIHK $_{t}+0,0002 D I H S G_{t}+0,0000005 D J U B_{t}$

t-stat: $(-0.876) \quad(-2.071) \quad(-.603) \quad(0.803)$

Prob: $(0.385)(0.0424) \quad(0.5484) \quad(0.4250)$

$$
+0,0002 D K U R S_{t}-0,367 E C T_{t-1}
$$

t-stat: $\quad(2.110)$

Prob: $\quad(0.0387)$
$(-2.750)$

$(0.0077)$

$\mathrm{R}^{2} \quad: 0.2219$

F-stat: $3.0416 \quad$ prob(F-stat): 0.01112

White Heteroscedasticity test:

Obs*R-squared : 20.0567 Prob. Chi-Square(20): 0.8284

Breusch-Godfrey Serial Correlation LM Test:

Obs*R-squared: 13.64997 Prob. Chi-Square(2): 0.0011

The following classical assumption test is the heteroscedasaticity test using White heteroskedasticity test. In equation 14 , it is informed that the calculated $\chi^{2}$ value as much as 20.0567 is smaller than the $\chi^{2}$ critical vale as much as 31.4104 or Prob. Value as much as 0.9789 is above $5 \%$, thus it can be inferred that there is no heteroscedascity.

In the ECM model, the Durbin-Watson test cannot be applied since DW statistic will asymptotically be refracted to approach the value of 2 (Arief 1993 in Kurniawan 2004). For this reason, Breusch-Godfrey (BG) or better known as Lagrange Multiplier (LM) Test is employed. The zero hypothesis in this test has no autocorrelation problem. This test is done by regressing squared residual with independent variables. Next, the $\mathrm{R}^{2}$ value is used to calculate $\chi^{2}$, where $\chi^{2}=(n-p) * \mathrm{R}^{2}$, and $p$ is the residual lag value in 
the residual model with independent variables. Criteria used are if the calculated $\chi^{2}$ is smaller than table $\chi^{2}$, then the zero hypothesis stating that there is no autocorrelation in the model is accepted, or if the prob. Is above $5 \%$ then autocorrelation does not exist. For model in equation 14, it is known that the LM-test value or calculated $\chi^{2}$ is as much as 13.64997 and Prob. 0.0011, thus it can be concluded that there is an autocorrelation. To better the long term equation, it is then used Cochran-Orcutt iterative method. The improved ECM model is written below.

$$
\text { DYSI }_{t}=-0,028-0,376 D S B I_{t}-0,004 D I H K_{t}+0,0002 D I H S G_{t}+0,0000002 D J U B_{t}
$$

t-stat: $(-0.777) \quad(-2.406) \quad(-0.780) \quad(0.346)$

$(0.276)$

Prob: $(0.4403)(0.0192) \quad(0.4384) \quad(0.7306) \quad$ (0.7838)

$+0,0003$ DKURS $_{t}-0,391 E C T_{t-1}-0,23 A R(3)$

t-stat: $\quad(2.552)(-2.931)$

$(-1.861)$

Prob: (0.0133) (0.0048) (0.0676)

$\mathrm{R}^{2}: 0.2692$

F-stat: $3.1567 \quad \operatorname{prob}($ F-stat): 0.006584

White Heteroscedasticity test:

Obs*R-squared :29.95090 Prob. Chi-Square(20): 0.7104

Breusch-Godfrey Serial Correlation LM Test:

Obs*R-squared: 5.36941 Prob. Chi-Square(3): 0.1467

In the ECM equation (equation 15), the coefficient of ECT variable, which is 0.391 , is significant (prob. value $=0.0048$ ), so the ECM model is valid and has a long term relationship in the ECM model. The value of ECT coefficient indicates that the 0.39 difference of YSI from its long term balance in the previous month will be non-existant 
this month. In equation15, it can be seen that DSBI and DKURS significantly affect yield spread (prob t-stat value below 5\%), while IHK and IHSG are not significant. While the effect of SBI is negative, that of KURS is positive. The improvement in the model does not change the conclusion of the equation 14. The F-statistic value of 3.1567 or probability 0.006584 indicates that all independent variables simultaneously influence yield spread. Furthermore, $\mathrm{R}^{2}$ shows that regression can explain the movement of yield spread as much as $29.95 \%$.

It can also be informed from equation 15 that there is no heteroscesdacticity problem. White heteroskedasticity test indicates the calculated $\chi^{2}$ value 29,95 is smaller than the $\chi^{2}$ critical value 31.4104 or Prob. value 0,9789 is bigger than 5\%. Meanwhile, the calculated $\chi^{2}$ value in LM test which is as much as 5,36941 is less than the $\chi^{2}$ critical value 7,8147 and Prob. Value 0,1467 means that there is no autocorrelaion issue.

\section{CONCLUSION}

This study finds that the macroeconomic variables affecting yield spread in the long term are interest rate, active circulation, and exchange rate. In the meantime, variables influencing yield spread in the short term are interest rate and exchange. Consumer Price Index and stock market, on the other hand, do noo say that the increasing interest (y effects on the yield spread both in a short and long term.

Interest rate has a negative influence on yield spread both in a short and long run. An increasing interest either in a long term or short term causes the yield spread to decrease. This decrease in yield spread is caused by the increasing bond yield with a shorter maturity. Interest chane also makes market players estimate that bond yield with a longer maturity is relatively lower. Since yield spread illustrates term structure of interest rate, we can say that the increasing interest (this research refers to BI rate) either in a long term or short term results in expectation that the future market interest will decrease. This research finding has similarities with the one by Ahmad et al (2009) showing that interest rate has a good balance both in a long term and short term with yield spread. 
The Effect of Macroeconomic Variables On The Yield Spread on Indonesian Government's Bond

Exchange rate also has a long term and short term balance with yield spread and has a positive sign. This condition is different from the initial prediction where the effect is negative. In investing, investors look at the return in the future, so the depreciation of rupiah, in fact, causes fund enter the market and rise the demand for bonds which can also be concluded that rupiah depreciation causes the market players, both in a short and long term, expect that there will be an increase in the market interest in the future. This positive relationship between exchange rate and yield spread similar to findings by Batten et al (2006)

Unlike the inerest and exchange rate variables, active circulation only has negative long term effect. This situation is shown by the significant coefficient of active circulation effect in the long term model and the insignificance in the ECM model. This research result demonstrates that only in a long run, the rise in active circulation leads to an increase in bond yield with short maturity. This rise of active circulation makes the market players foresee a decrease of market interest in the future. The presence of active circulation effect on yield spread is the same as the research conducted by Fah (2011). The difference is, due to using OLS method, Fah (2011) does not indicate the short term effect of active circulation. Similarly, research by Batten et al. (2006) found the effect of exchange rate and interest on yield spread.

In this study, IHK variable illustrating real sector and IHSG describing the substitution of bond do not affect yield spread both in the long and short term. The non-existence influence of IHK is in line with the one conducted by Fah (2011), Ahmadet al. (2009), and Min (1998). On the contrary, this research result is against the study by Sihombing et al. (2012) which demonstrates the effect of IHK on yield spread in Indonesia. Meanwhile, the nonexistence of IHSG effect does not conform finding by Ahmad et al (2009) who found the long term and short term effect of interest, but only a long term effect of Malaysia stock price index (KLCI).

The change of interest in a short term is adjusted by the market, so the policy that alters the interest quickly is anticipated by the market. Also, exchange rate which is more difficult to control, is quickly anticipated by the market abd can be the source of fluctuation in the bond market. Different from interest and exchange rate, active circulation has effect on yield spread only in the long term, so if there is a surprise in the active circulation, it will be adjusted by the market in a relatively long time. Next, IHK which represents real sector variable and IHSG which shows substitution of bond turn out to have no effect on yield spread. Based on the theory 
term structure of interest rate this research result proves that interest (BI rate), exchange rate, and active circulation affect market estimation regarding future interest.

\section{REFERENCES}

Ahmad, N., Muhammad, J., \& Masron, T.A. (2009). Factors Influencing Yield Spreads Of The Malaysian Bonds. Asian Academy of Management Journal.14.2. 95-114.

Batten, J.A., Fetherston, T.A., \& Hoontrakul, P. (2006). Factors Affecting The Yields of Emerging Market Issuers: Evidence From The Asia-pasific region. Journal of International Finance Markets, Institution and Money. 16. 57-70.

Blanchard, O. (2011). Macroeconomics. (5th ed). Pearson.

Direktorat Jenderal Pengelolaan Utang. (2014). Buku Saku Perkembangan Utang Negara edisi Januari 2014. Diunduh pada 23 Juni 2014 dari http://www.djpu.kemenkeu.go.id/index.php/page/loadViewer?idViewer=3800\&action=d ownload

Direktorat Jenderal Pengelolaan Utang. (2014). Laporan Analisis Portfolio dan Risiko Utang Tahun 2013.Diunduh pada 23 Juni 2014 dari http://www.djpu.kemenkeu.go.id/index.php/page/loadViewer?idViewer=4055\&action=d ownload

Fabozzi, J.F., Modigliani, F.P., \& Jones, F.J. (2010).Foundations Of Financial Markets And Institutions. (4th ed). Prentice Hall.

Fah, F.C. (2011). Factors Correlated With Treasury Bond Spreads In An Emerging Capital Market. International Journal of Humanities and Social Science. 1.5.

Federal Reserve Bank of San Francisco (FRBSF). (2003). What The Yield Curve Move?,FRBSF Economic Letter. Diunduh pada 7 Juli 2014 dari http://www.frbsf.org/economicresearch/publications/economic-letter/2003/june/what-makes-the-yield-curve-move/

Gujarati, D.N. (2003). Basic Econometrics.4th edition. New York: Mc-Graw Hill.

Handa, J. (2009). Monetary Economics. $2^{\text {nd }}$ edition. London: Taylor \& Francis Group.

Lnsukindro (1991). Regresi Linear Lancung dalam Analisa Ekonomi : Studi Kasus Permintaan Deposito Dalam Valuta Asing di Indonesia, Jurnal Ekonomi dan Bisnis Indonesiavolume 1 No.1

Kurniawan, T., (2004), Determinan Tingkat Bunga Pinjaman di Indonesia Tahun 1983-2002, Buletin Ekonomi Moneter dan Perbankan, Bank Indonesia.

Lewis, M.K., \& Mizen, P.D. (2000).Monetary Economics. New York: Oxford.

Min, G.H. (1998). Determinants Of Emerging Market Bond Spread: Do Economic Fundamentals $\begin{array}{llllll}\text { Matter. Diunduh } & \text { pada } & 30 & \text { Januari } & 2014 & \text { dari }\end{array}$ http://elibrary.worldbank.org/doi/pdf/10.1596/1813-9450-1899 
The Effect of Macroeconomic Variables On The Yield Spread on Indonesian Government's Bond

Otoritas Jasa Keuangan. (2014). Statistik Pasar Modal: Januari 2014. Diunduh pada 3 Juli 2014 dari http://www.ojk.go.id/januari-minggu-1-2014

Sihombing, P. et al (2012). Analisis Pengaruh Makroekonomi Terhadap Term Structure Interest Rate Obligasi Pemerintah (SUN) Indonesia.Jurnal Pasar Modal dan Perbankan.1.2. 103114

Thomas, R.L. (1997). Modern Econometrics an Introduction. Addison-Wesley: England. 